\title{
Potential of the filamentous fungus Aspergillus niger AN 400 to degrade Atrazine in wastewaters
}

\author{
G. Marinho ${ }^{\mathrm{a}}$, B.C.A. Barbosa ${ }^{\mathrm{b}}$, K. Rodrigues ${ }^{\mathrm{a}}$, M. Aquino ${ }^{\mathrm{b}}$, L. Pereira $^{\mathrm{c}, *}$ \\ a Campus of Fortaleza, Department of Chemistry and Environment, Avenue May 13 number 2081, 60040-215 Benfica, Fortaleza, Ceará, Brazil \\ b Campus of Pici, Department of Hydraulic and Environmental Engineering, DE Block 713, 1st Floor, Technology Center, 60451-970, Brazil \\ ${ }^{\mathrm{c}}$ CEB - Centre of Biological Engineering, University of Minho, 4710-057 Braga, Portugal
}

\section{A R T I C L E I N F O}

Keywords:

Allium test

Aspergillus niger

Atrazine

Biodegradation

Glucose

Substrate competition kinetics

\begin{abstract}
A B S T R A C T
This research aims to evaluate the ability of the fungal specie Aspergillus niger AN 400 to metabolize atrazine (ATZ) in model wastewaters, as most of the research with this worldwide used herbicide is focused on bacteria and on soil bioremediation. Firstly, the tolerance of $A$. niger for ATZ was evaluated in petri dishes. A. niger growth in all the tested ATZ concentrations, up to $30 \mathrm{mg} \mathrm{L}^{-1}$. Biodegradation of ATZ was then conducted in batch reactors of $3 \mathrm{~L}$, with dispersed fungal biomass. Reactors were operated for 8 days at different conditions: without glucose (RG0) and glucose at concentrations of $0.5 ; 1.0 ; 2.0 ; 3.0 ; 4.0$ and $5.0 \mathrm{~g} \mathrm{~L}^{-1}$ - RG0.5; RG1; RG2; RG3; RG4 and RG5, respectively. Control (RC) includes a reactor in the absence of fungal spores. The highest ATZ removal, 72\%, occurred in RG3. At higher glucose concentration, substrate competition kinetics may be the responsible for the decrease of biodegradation rate constants. Only 50\% of Chemical Oxygen Demand (COD) removal was obtained due to the presence of methanol used to dissolve ATZ, which has contributed for most of the COD in reactors. Detoxification of the ATZ solution by the biological treatment was observed by the Allium test.
\end{abstract}

\section{Introduction}

Environmental contamination by industrial effluents is one of the major challenges of the modern world as most of the release compounds are xenobiotic (Ramadevi et al., 2012). Agro chemicals are among the existing pollutants, which were comproved to present toxicity to the environment and Human health (Sene, 2010). Agro compounds, including pesticides, play an important role in modern agriculture, however their indiscriminate use is a serious danger for the environment and human health (Pereira, 2013). In the international context, Brazil is since 2008 the highest consumer of agro compounds (Sindag, 2011). The abusive use of such chemicals caused, in 2011, 485 cases of contamination and 40 Human dead in the northeast of Brazil. The total of lethality in Brazil in 2011 was 2.48\%, an alarming percentual. According to the National Agency of Sanitary (ANVISA) in Brazil (ANVISA, 2011), the main group of agrotoxics commercialized is herbicides, representing 45\%. ATZ [2-chloro-4-(ethylamino)-6(isopropylamino)-s-triazine], is a widely-used herbicide including Brazil (Coelho and Di Bernardo, 2012). ATZ has low reactivity and solubility and can be frequently found in soils, rivers and groundwater
(Vonber et al., 2014). Its detection in groundwater and surface water, due to its low adsorption on soil and moderate solubility, is of public and human health concern, specially owning its recalcitrant nature and persistence in the environment (Fan and Song, 2014). Moreover, according to ANVISA- Brazil, ATZ is considered as class III in terms of toxicity (ANVISA, 2010). Sánchez-Sánchez et al. (2013), have classified ATZ as an endocrine disruptor, as the continuing exposition to it can induce cancer and congenital bad formations.

Various treatment processes, such as fito and bioremediation, have been developed aiming to remove pesticides from effluents generated by industries. The high interest for those biological processes, as compared with conventional ones such as coagulation, flocculation, sedimentation, etc., is mainly due to the lower costs and simplicity of treatment units. Additionally, some of the conventional processes contribute to other type of pollution as many chemicals are employed. Bacteria have been largely used on pesticide biodegradation. As example, Kolekar et al. (2014) studied ATZ biodegradation by the bacteria Rhodococcus sp. BCH2 in liquid medium and the effect of different carbon and nitrogen sources. Under the best conditions, 75\% of ATZ biodegradation was obtained. However, the fungi are primary

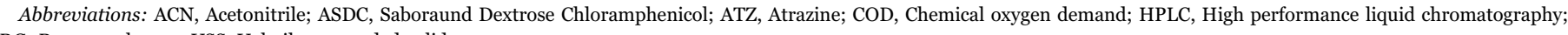
RG, Reactor, glucose; VSS, Volatile suspended solids

* Corresponding author.

E-mail address: lucianapereira@deb.uminho.pt (L. Pereira). 
decomposers that tolerate adverse conditions for their growth and, as compared to bacteria, react better to toxic compounds (Tortora et al., 2012). White-rot fungi are the main class of fungi degrading atrazine due to their lignin-degrading system (Fan and Song, 2014). Kaufman and Blake (1970) found that Aspergillus sp., namely Aspergillus fumigatus, Aspergillus ustus and Aspergillus flavipes, are able to degrade atrazine, in soil, via N-dealkylation of either alkylamino groups. The present study aims the evaluation, for the first time, of the filamentous fungi specie A. niger AN 400 to degrade ATZ at concentration of $30 \mathrm{mg} \mathrm{L}^{-1}$. A. niger has been reported as good degrader of many compounds that are example the aromatic and aliphatic hydrocarbons (Elshafie et al., 2007; Wang et al., 2008) and insecticide (Bhalerao et al., 2007), but was never reported as degrading atrazine. Usually, the concentration of ATZ found in soils is lower than $30 \mathrm{mg} \mathrm{L}^{-1}$, but in industrial effluents it can reach values in this range (Ghosh and Philip, 2006). Most of the studies on pesticide biodegradation are focused on soils, therefore we aim to explore their fate in wastewater. The capacity of A. niger AN 400 to tolerate concentrations up to $30 \mathrm{mg} \mathrm{L}^{-1}$ was evaluated. The effect of glucose as co-substrate of ATZ biodegradation by $A$. niger was studied at concentrations in the range $0.5-5 \mathrm{~g} \mathrm{~L}^{-1}$. Toxicity of atrazine solution before and after the biological treatment was assessed by the Allium test.

\section{Experimental}

\subsection{Chemicals}

ATZ was obtained from the commercial formulated Gesaprim ${ }^{\circledast}$ with $500 \mathrm{~g} \mathrm{~L}^{-1}$ of active ingredient. ATZ stock solution with a final concentration of $1500 \mathrm{mg} \mathrm{L}^{-1}$ was prepared from the commercial one by dilution with deionized water and methanol at the proportion of 3:2 (vol/vol). The molecular structure of ATZ is available in Fig. 1A. Acetonitrile (ACN) for HPLC analysis was purchased from Sigma Aldrich $^{\circledR}$.

\subsection{A. niger $A N 400$ cultivation}

A. niger strain, granted by environmental technology laboratory (LATAM) at Federal Institute of Ceará, was platted on culture Saboraund Dextrose Chloramphenicol (ASDC) agar as the culture media (Acumedia, Baltimore), supplemented with $1 \mathrm{~mL}$ of Vishniac solution $\left(\mathrm{g} \mathrm{L}^{-1}\right)$ : EDTA (10.00), $\mathrm{ZnSO}_{4} \cdot 7 \mathrm{H}_{2} \mathrm{O}$ (4.40); $\mathrm{MnCl}_{2} \cdot 4 \mathrm{H}_{2} \mathrm{O}$ (1.00); $\mathrm{CoC}_{12} \cdot 6 \mathrm{H}_{2} \mathrm{O}(0.32) ;\left(\mathrm{NH}_{4}\right) 6 \mathrm{Mo}_{7} \mathrm{O}_{24} \cdot 4 \mathrm{H}_{2} \mathrm{O}(0.22) ; \mathrm{CaCl}_{2} \cdot 2 \mathrm{H}_{2} \mathrm{O}$ (1.47) and $\mathrm{FeSO}_{4} \cdot 7 \mathrm{H}_{2} \mathrm{O}$ (1.00). Plates were then incubated at $\pm 28{ }^{\circ} \mathrm{C}$ in a microbiological BioPar $^{\circledR}$ incubator during seven-days. After that period, the spores were removed with a Tween 80 solution, forming a spore suspension which was removed from the surface of the plates using an automatic pipette, transferred to $200 \mathrm{~mL}$ sterile bottles, where it was stored at $4{ }^{\circ} \mathrm{C}$. In order to count the spores, the spore solution was diluted 1:20 with Tween $80(50 \mu \mathrm{L}$ of the spore suspension to $950 \mu \mathrm{L}$ of Tween 80 ). Then, $20 \mu \mathrm{L}$ of the prepared solution were transferred to a Neubauer chamber and the spores were counted in an
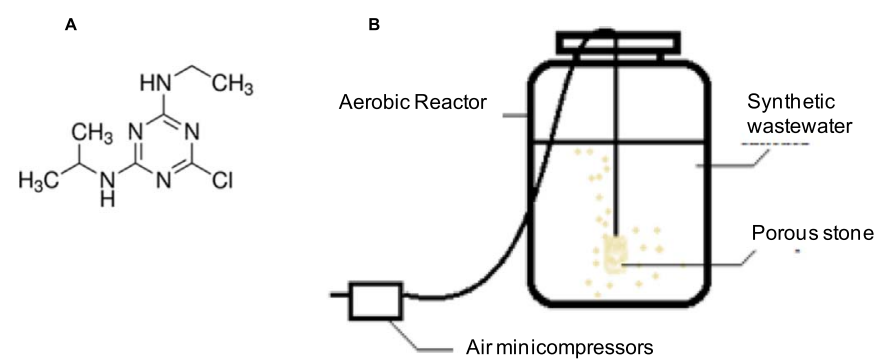

Fig. 1. Molecular structure of atrazine (A) and scheme of the reactors used in the aerobic degradation of ATZ (B). optical microscope Bioval ${ }^{\circledR}$.

\subsection{Effect of $A T Z$ concentration on A. niger growth}

In order to evaluate the concentrations that A. niger can tolerate, prior to select the ATZ concentration to be tested in bioreactors, the fungus was platted on Petri dishes containing ASDC media, but in the presence of increasing concentrations of ATZ from 5 to $30 \mathrm{mg} \mathrm{L}^{-1}$. The maximum ATZ concentration tested was based in the maximum value of solubility Kaufman and Blake (1970). The concentration of $A$. niger spores inoculated was $2 \times 10^{6}$ spore $\mathrm{mL}^{-1}$. The diameter of $A$. niger spore growth was measured every day during 6 days, time at which the fungi in control occupied all the plate.

\subsection{Aerobic biodegradation of atrazine}

ATZ biodegradation was conducted under aerobic conditions in batch reactors of $3 \mathrm{~L}$ (Fig. 1B), containing the model wastewater composed of a Vishniac solution, ATZ at a concentration of $30 \mathrm{mg} \mathrm{L}^{-1}$ and $A$. niger AN 400 spores, $2 \times 10^{6}$ spore $\mathrm{mL}^{-1}$. As ATZ stock solution has methanol, the final concentration of methanol in reactors was $7.9 \mathrm{mg} \mathrm{L}^{-1}$. Air was supplied by minicompressors with a flow $20 \mathrm{~L} \mathrm{~h}^{-1}$. The presence of porous stones was to facilitate oxygen diffusion. Reactors were operated, in duplicate, at different conditions: without glucose (RG0) and with glucose ranging from 0.5 to $5 \mathrm{~g} \mathrm{~L}^{-1}$, namely RG 0.5, RG1, RG2, RG3, RG4 and RG5, respectively. Control reactors for each condition, but without spores, were also ran (RC0, $\mathrm{RC} 0.5, \mathrm{RC} 1, \mathrm{RC} 2, \mathrm{RC} 3, \mathrm{RC} 4, \mathrm{RC} 5)$. Reactors were operated for 8 days and samples were withdrawn daily for analysis.

\subsection{Toxicity evaluation of atrazine and treated wastewater by Allium} test

The toxicity of ATZ solution before and after the biological treatment was evaluated by the standard Allium test, using Allium cepa L. (onion). The experiment was performed as described by Fiskesjo (1985) with minor modifications. The advantage of using onion in the toxicity tests is the low costs, easy and rapid growth, and being able to use to evaluate acute and chronic toxicity. The monitoring mechanism is based on the contact of onion with the water containing compounds to be evaluated. When the bulb comes into contact with nontoxic water, stimulation of roots growth occurs. However, when inhibitors are present in the water, a delay of cell division, or total inhibition, and thus of growth of roots will happen. Onions where chosen based on their similarities (shape and size) and their shells and roots were carefully removed. The onions were then placed in plastic cups containing deionised water and left in a place protected from light and of low humidity for $72 \mathrm{~h}$ at $20^{\circ} \mathrm{C}$. After three days, the onions were removed from the water and the roots growth was measured with a ruler. For the toxicity test, the onions that have shown similar roots growth were selected. The growth roots were removed and the base of the bulbs were placed in plastic cups with the wastewater containing the $30 \mathrm{mg} \mathrm{L}^{-1}$ of atrazine (sample before treatment) and of the reactor outlet (after biological treatment with Aspergillus niger AN 400). Cups were left in a place protected from light and of low humidity for $72 \mathrm{~h}$ at $20^{\circ} \mathrm{C}$. The assay was conducted in triplicate. After $72 \mathrm{~h}$ the roots were measured with a ruler. As a negative control, onions exposed only with water were used. The inhibition percentage was calculated by compared the growth of roots in the presence of the compound to be tested with that of using only deionised water.

\subsection{Analytic analysis}

COD, volatile suspended solids (VSS) and $\mathrm{pH}$ were measured according to APHA (2005) procedures. ATZ concentration was determined be High performance liquid chromatography (HPLC) in an 
A

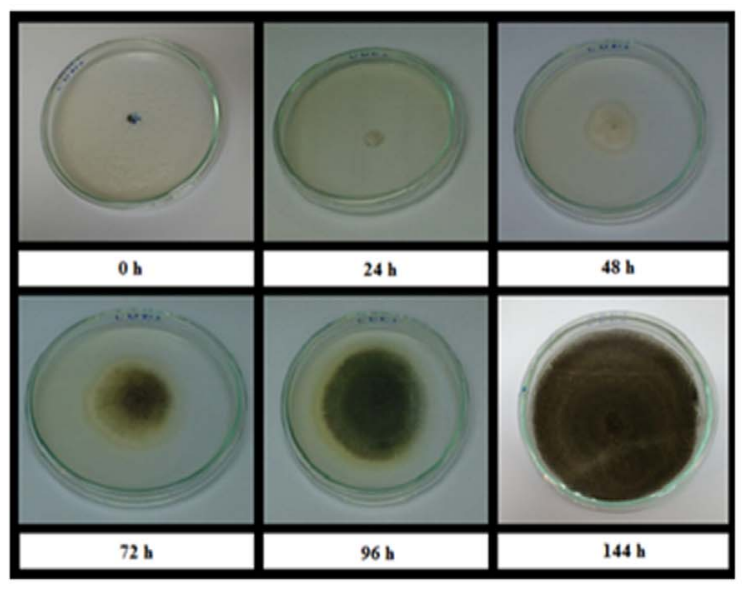

B

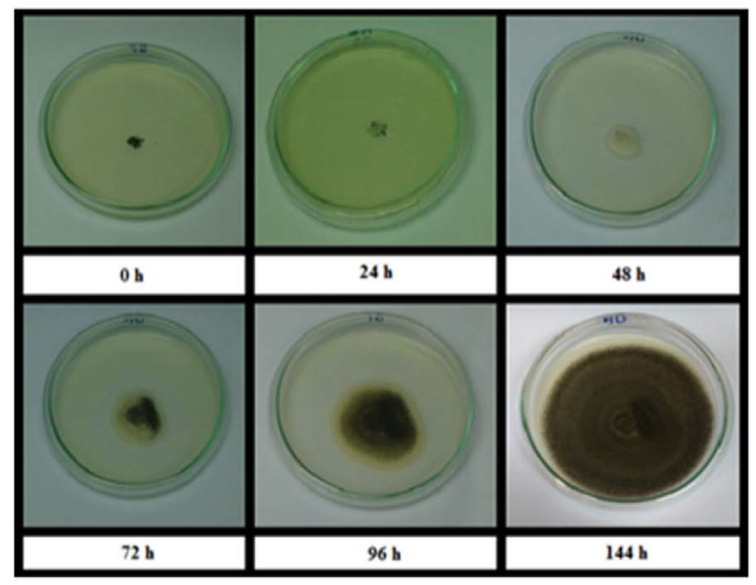

Fig. 2. Grown of A. niger on plates without ATZ (A) and with $30 \mathrm{mg} \mathrm{L}^{-1}$ of ATZ (B).

HPLC Shimadzu (LC-10 CE) equipment with a Diode Array detector (SPD-10AVP). A C18 reverse phase Supelco column $(250 \mathrm{~mm} \times 4.6 \mathrm{~mm}$, $5 \mu \mathrm{m}$ particle size) was used. Mobile phase was composed of two solvents: deionized water and ACN. Elution was made at a flow of $1.0 \mathrm{~mL} \mathrm{~min}{ }^{-1}$ and at room temperature, with isocratic condition of $85 \%$ of $\mathrm{ACN}$, over $8 \mathrm{~min}$. The injection volume was $50 \mu \mathrm{L}$. Detection was made at $220 \mathrm{~nm}$. Ammonia was performed by direct nesslerization method as APHA.

\section{Results}

\subsection{Effect of $A T Z$ concentration on A. niger growth}

The effect exerted by ATZ on A. niger was evaluated at increasing ATZ concentrations. A. niger growth was followed and the diameter covered by spores on the plates was measured (Fig. 2). Among the concentrations tested, growth was very similar, although at lower rate than in the control plates (Table 1). Nevertheless, after 6 days, the diameter of spores on dishes was similar at all the tested conditions covered the entire diameter $(\sim 9 \mathrm{~cm})$. The results obtained indicate that A. niger tolerates high concentrations of this pesticide, so being a potential microorganism for bioremediation of sites contaminated with high levels of this pesticide, such as residual effluents or water bodies and soils where they were accumulated.

This result is consistent with the fact that filamentous fungi are organisms having high resistance and capacity to adapt and grow in extreme environmental conditions, such as in contaminated areas, and long term stability (Bučková et al., 2007). As example, A. niger was reported has having the capacity to resist and grow under concentrations of arsenic of $300 \mathrm{mg} \mathrm{L}^{-1}$ (Cernanský et al., 2009).

Table 1

Diameter (cm) of A. niger spores on Petri dishes incubated with increasing concentrations of ATZ.

\begin{tabular}{llllll}
\hline \multirow{2}{*}{ Time (d) } & \multicolumn{5}{l}{ ATZ concentration $\left(\mathrm{mg} \mathrm{L}^{-1}\right)$} \\
& 0 & 5 & 10 & 20 & 30 \\
\cline { 2 - 6 } & 0 & 0.8 & 0.9 & 0.7 & 0.9 \\
\hline 0 & 0.7 & 0.9 & 1.3 & 0.9 & 1.0 \\
1 & 1.2 & 1.9 & 2.0 & 1.8 & 1.6 \\
2 & 2.5 & 3.4 & 3.2 & 3.1 & 2.7 \\
3 & 4.4 & 5.1 & 4.6 & 4.3 & 4.3 \\
4 & 6.6 & 8.9 & 9.2 & 8.8 & 8.6 \\
7 & 9.0 & & & & \\
\hline
\end{tabular}

Table 2

Extent and rates of ATZ removal and extent of COD removal, in aerobic bioreactors. In control reactors (RC0-RC5), without biomass, ATZ removal did not occur.

\begin{tabular}{llll}
\hline Reactor & $\begin{array}{l}\text { Extent of ATZ } \\
\text { removal (\%) }\end{array}$ & $\begin{array}{l}\text { Rate of ATZ removal } \\
\left(\mathrm{d}^{-1}\right)\end{array}$ & $\begin{array}{l}\text { Extent of COD } \\
\text { removal }(\%)\end{array}$ \\
\hline RG0 & $40 \pm 3$ & $0.29 \pm 0.06$ & $25 \pm 4$ \\
RG0.5 & $44 \pm 6$ & $0.20 \pm 0.01$ & $27 \pm 2$ \\
RG1 & $34 \pm 4$ & $0.18 \pm 0.01$ & $34 \pm 1$ \\
RG2 & $59 \pm 1$ & $0.19 \pm 0.03$ & $37 \pm 5$ \\
RG3 & $72 \pm 2$ & $0.48 \pm 0.06$ & $50 \pm 3$ \\
RG4 & $61 \pm 2$ & $0.14 \pm 0.05$ & $41 \pm 1$ \\
RG5 & $62 \pm 2$ & $0.12 \pm 0.01$ & $39 \pm 1$ \\
\hline
\end{tabular}

\subsection{Biodegradation of ATZ by A. niger}

ATZ degradation occurred in all the operated reactors containing $A$. niger AN 400 spores (Table 2). The reaction followed first order kinetics (Fig. 3A) and rate constants were calculated in OriginPro 6.1 software, applying the equation $\mathrm{C}_{\mathrm{t}}=\mathrm{C}_{0} \mathrm{e}^{-\mathrm{kt}}$, where $\mathrm{C}_{\mathrm{t}}$ is the concentration at time $\mathrm{t} ; \mathrm{C}_{0}$, the concentration at time zero and $\mathrm{k}$, the first-order rate constant $\left(\mathrm{d}^{-1}\right)$. In the absence of glucose, in RG0, only $40 \%$ of ATZ degradation was obtained, at a constant rate of $(0.29 \pm 0.06) \mathrm{d}^{-1}$. The presence of glucose at the concentrations of 0.5 and $1.0 \mathrm{~g} \mathrm{~L}^{-1}$ had no effect on ATZ removal; however, for the other tested concentrations the effect of glucose was evident and higher percentages of ATZ removal were achieved, as compared with the results obtained in RG0. Concerning the rates of ATZ biodegradation, in RG3 it occurred at a 2-fold higher rate $(0.48 \pm 0.06) \mathrm{d}^{-1}$ as compared with RG0 and the final ATZ removal extent was higher than in all the other reactors, $(72 \pm$ 2)\%. Contrarily, at concentrations above $3.0 \mathrm{~g} \mathrm{~L}^{-1}$, although the final extent of ATZ degradation reached higher values than in RG0.5, RG1 and RG2, rates of ATZ degradation decreased significantly, probably due to substrate competition kinetics. Glucose is the primary/preferred substrate for eukaryotic microorganisms so, when glucose is present, in many organisms the genes that are used to metabolize other carbon sources are dispensable being repressed to save energy.

The obtained results are in accordance with previous studies where an additional carbon source was needed by microorganisms for an efficient degradation of persistent organic compounds (Fontana and Silveira, 2012; Getenga et al., 2009; Xie et al., 2013). Other authors, for instance Silva et al. (2013), have tested the capability of Cunninghamella elegans to degrade phenanthrene in aqueous media, varying the glucose concentration $\left(0.6 \mathrm{~g} \mathrm{~L}^{-1}\right.$ and $\left.6 \mathrm{~g} \mathrm{~L}^{-1}\right)$ and better 

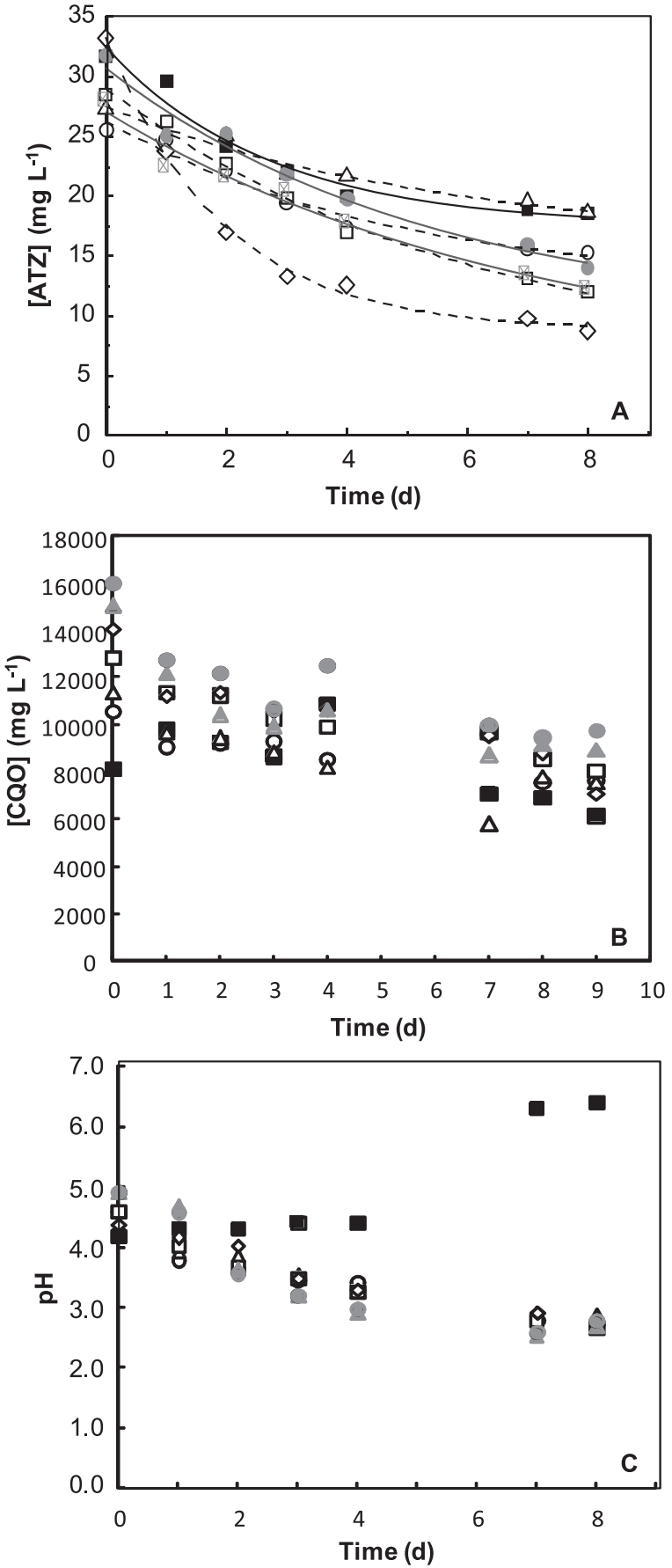

Fig. 3. (A) First-order curves o ATZ degradation, (B) CQO removal and (C) pH profile during operation of the reactors. Standard deviation errors are less than $5 \%$. In control reactors (RC0-RC5) ATZ and CQO removal did not occur. RG0 (ש), RG0.5 (O), RG1 ( $\Delta$ ),

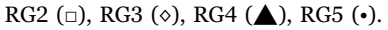

removal was obtained with $0.6 \mathrm{~g} \mathrm{~L}^{-1}$. High glucose concentration has inhibited cellular growth. Contrarily, in the study of Fontana and Silveira (2012), glucose has favored cellular growth of fungi and bacteria. In the present study, according to the Volatile Suspended Solids (VSS), growth of $A$. niger was similar in all the bioreactors (2.8 $\pm 0.6) \mathrm{g} \mathrm{L}^{-1}$, except in R4 and R5, where VSS after 8 days was 8.5 and $7.9 \mathrm{~g} \mathrm{~L}^{-1}$, respectively. In terms of COD, initial values varied in bioreactors, increasing with increase on glucose concentration (Fig. 3B). In abiotic reactors, COD was constant over the entire operation period. In bioreactors, COD removal in RG0 was (25 \pm 4$) \%$, but in the presence of glucose COD removal improved with the increase of glucose concentration up to $3.0 \mathrm{~g} \mathrm{~L}^{-1}$, at which the maximal COD removal of $(50 \pm 3) \%$ was achieved. At higher concentrations of glucose, in RG4 and RG5.0, COD removal was approximately $40 \%$ (Table 2). The low diminish of COD and, so, the high COD values at the end of the experiment, may be related with the presence of methanol which contributed to high COD of the media. ATZ contributed only with $260 \mathrm{mg} \mathrm{L}^{-1}$ of COD but the methanol used to dissolve ATZ contributed with $7090 \mathrm{mg} \mathrm{L}^{-1}$ of COD. ATZ is not totally mineralized and their degradation products may contribute equally for the CQO values. For instance, phenol has been reported as one of the products of aerobic biologic degradation of ATZ (Mudhoo and Garg, 2011). However, degradation of phenolic compounds by A. niger has been also observed by Lopes et al. (2011). Authors studied the effect of glucose on the degradation of phenolic compounds contained in the industrial effluent of cashew nut, concluding that the increase of cosubstrate had no influence either on phenolic compounds degradation and on COD removal. Nevertheless, the COD contribution of ATZ and of formed products is low as compared with that of methanol.

As can be observed in Fig. $3 \mathrm{C}$, in reactors with glucose the $\mathrm{pH}$ decreases from $\sim 5$ to $\sim 3$, in opposite to what happens in the reactor operated in the absence of glucose, which is maintained during the first 4 days of operation and then increases to 6.5. The $\mathrm{pH}$ decrease in bioreactors with glucose is explained by the products formed during glucose metabolism. Increase of $\mathrm{pH}$ in bioreactors without glucose may be related with the consumption of acids present in the medium, in order to regulate internal $\mathrm{pH}$ of the cell (Raimbault, 1998). Additionally, aerobic biodegradation of ATZ originates $\mathrm{NH}_{3}$, which may also increase the $\mathrm{pH}$ in bioreactors without glucose. In bioreactors with glucose, the $\mathrm{NH}_{3}$ formed has no capacity to buffer the medium due to the acids resulted from glucose metabolism (Papagianni, 2007). Formation of $\mathrm{NH}_{3}$ was confirmed in all the bioreactors with high concentration in RG0 (data not show). The optimum $\mathrm{pH}$ for $A$. niger is 5 , however it is described in literature that it can tolerate a wide range of $\mathrm{pH}$ values (2-11) (Papagianni, 2007). Taking this into account, the changes of the $\mathrm{pH}$ in bioreactors may not have influenced ATZ biodegradation. In abiotic reactors, the $\mathrm{pH}$ was constant.

\subsection{Toxicity of atrazine and treated wastewater}

Toxicity of atrazine solution, prior and after the biological treatment, was evaluated towards Allium cepa $\mathrm{L}$. The results of roots growth are shown in Table 3. In the blank, root growth after contacting with deionised water, $(2.8 \pm 0.2) \mathrm{cm}$ was achieved (Fig. 4A). Any growth was obtained with the atrazine solution, indicating the high toxicity of the pesticide (Fig. 4B). Nevertheless, after the biological treatment, roots of $(1.5 \pm 0.3) \mathrm{cm}$ were obtained, demonstrating that the treated solution is less toxic, $54 \%$, than the initial solution (Fig. 4C). The high toxicity obtained with the ATZ solution is in accordance with previous results reported. For instance, Bolle et al. (2004) have observed a mitotic delay and an increase in the number of total somatic chromosome aberrations on bulbs exposed to ATZ concentrations of $5 \mu \mathrm{g} \mathrm{L}{ }^{-1}$. The largely type of damage was chromosome break, suggesting a clastogenic effect. ATZ toxicity to other organisms, including algae (Kabra et al., 2014; Satyavani et al., 2012), fisch (Nwani et al., 2010; Solomon et al., 2008) and amphibians, and aquatic reptiles (Solomon et al., 2008) was also reported. According to Eisler (1989), there is a general consensus that

Table 3

Growth of roots of the onions after the contact with atrazine (sample before treatment) and after the biological treatment with $A$. niger. The growth inhibition percentage was calculated as compared with the blank made with tap water.

\begin{tabular}{lll}
\hline Sample & $\begin{array}{l}\text { Root growth } \\
\text { (cm) }\end{array}$ & $\begin{array}{l}\text { Growth inhibition } \\
\text { (\%) }\end{array}$ \\
\hline Blank & $2.8 \pm 0.2$ & 0 \\
Before treatment & 0 & 100 \\
After biological treatment & $1.3 \pm 0.3$ & 54 \\
\hline
\end{tabular}



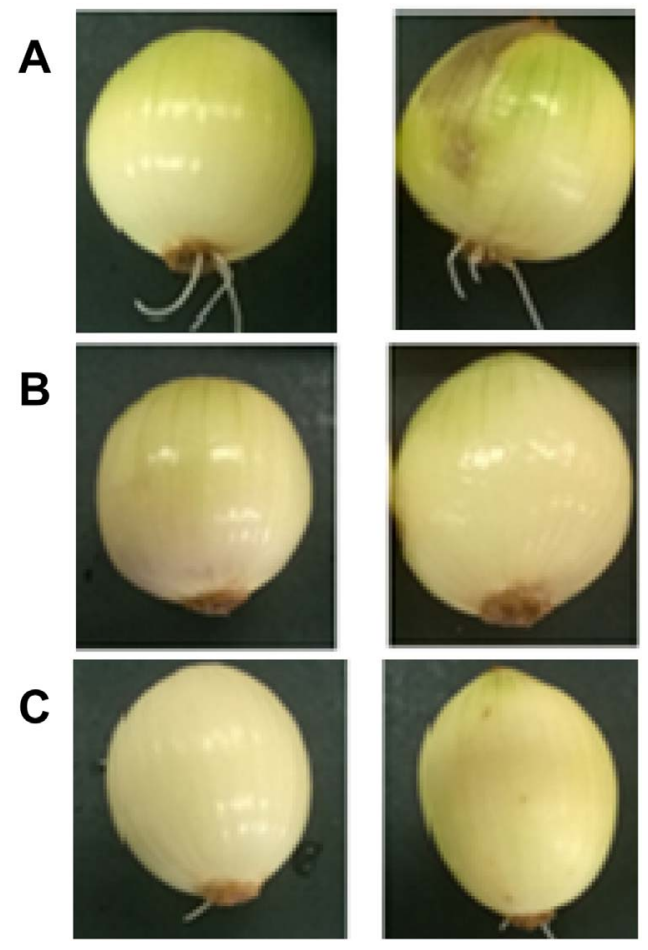

Fig. 4. Photography of the onions root growth (Allium test) when exposed to deionized water (A); to ATZ solution previous (B) and after the to the biological treatment with $A$. niger $(\mathrm{C})$.

ATZ degradation products are substantially less toxic and, normally, are not present in the environment at inhibitory concentrations for algae, bacteria, plants or animals. Solomon et al. (1996), have evaluated the toxicity of ATZ and four degradation products (DEA deethylatrazine), DIA (deisopropilatrazine), HA (hydroxyatrazine) and DEDIA (atrazine desetilisopropil) and observed that ATZ inhibited more effectively the photosynthesis than any of their degradation products. ATZ was 7-10 times higher than DEA for blue algae and 4-6 times more toxic than DEA for green algae. With respect to the DIA metabolite, ATZ was 20-50 times more inhibitory to blue algae and 7-13 times more inhibitory to green algae. DEDIA and HA were considered in this study as nontoxic to these algae.

\section{Conclusions}

By testing the effect of increasing atrazine concentrations on $A$. niger AN 400, it was concluded that this fungus is very resistant to the studied pesticide, and so it is a very promising microorganism for the treatment of wastewaters highly contaminated with ATZ. The fungi $A$. niger AN 400 was capable of growing in the presence of ATZ at concentrations up to $30 \mathrm{mg} \mathrm{L}^{-1}$. In bioreactors, $A$. niger could degrade ATZ in the absence of a co-substrate. The addition of glucose at concentrations of 0.5 and $1.0 \mathrm{~g} \mathrm{~L}^{-1}$ had no effect on the process, however, with $3.0 \mathrm{~g} \mathrm{~L}^{-1}$, the constant rate of ATZ degradation duplicated and the final ATZ removal increased $30 \%$. Increasing the glucose to 4.0 and $5.0 \mathrm{~g} \mathrm{~L}^{-1}$, though the $60 \%$ of ATZ biodegradation, constant rates decreased significantly probably due to competition between both substrates and gene repression by glucose. The low COD removal may be explained by the methanol present in the media. $46 \%$ of detoxification was achieved by the biological treatment with A. niger AN 400 as assessed by the Allium test.

\section{Declaration of interest}

The authors report no declarations of interest.

\section{Acknowledgements}

The authors thank CAPES for the PhD scholarships and wich and CNPQ there search productivity grantPQ2(311203/2012-4) and the bagPDE(200444/2014-0). Acknowledges also to the Portuguese Foundation for Science and Technology (FCT) under the scope of the strategic funding of UID/BIO/04469/2013 unit and COMPETE 2020 (POCI-01-0145-FEDER-006684) and BioTecNorte operation (NORTE01-0145-FEDER-000004) funded by European Regional Development Fund under the scope of Norte2020 - Programa Operacional Regional do Norte. Luciana Pereira a post-doc fellowship (SFRH/BPD/110235/ 2015) from FCT.

\section{References}

American Public Health Association - APHA, 2005. Standard Methods for Examination of Water and Wastewater. Publishers Denver: APHA.

ANVISA, 2011. Agência Nacional de Vigilância Sanitária (National Health Surveillance Agency), Programa de Análise de Resíduo de Agrotóxico em Alimentos (PARA), dados da coleta e análise de alimentos de 2010 (Pesticide Residue Analysis Program in Food (PRAPF), collecting data and 2010 food analysis). 〈http://portal.anvisa.gov. $\mathrm{br} / \mathrm{wps} /$ content/Anvisa+Portal/Anvisa/Inicio/Agrotoxicos+e+Toxicologia/Assuntos +de+Interesse/Programa+de+Analise+de+Residuos+de+Agrotoxicos+em +Alimentos> (acessed 23.10.2015).

Bhalerao, T.S., Puranik, P.R., 2007. Biodegradation of organochlorine pesticide, endosulfan, by a fungal soil isolate, Aspergillus niger. Int. Biodeterior. Biodegrad. 59 (4), 315-321.

Bolle, P., Mastrangelo, S., Tucci, P., Evandri, M.G., 2004. Clastogenicity of atrazine assessed with the Allium cepa test. Environ. Mol. Mutagen. 43 (2), 137-141.

Bučková, M., Godočíková, J., Polek, B., 2007. Responses in the mycelial growth of Aspergillus niger isolates to arsenic contaminated environments and their resistance to exogenic metal stress. J. Basic Microbiol. 47, 295-300.

Cernanský, S., Kolencík, M., Sevc, J., Urík, M., Hiller, E., 2009. Fungal volatilization of trivalent and pentavalent arsenic under laboratory conditions. Bioresour. Technol. 100, 1037-1040.

Coelho, E.R.C., Di Bernardo, L., 2012. Removal of atrazine and metabolites by slow filtration bed of sand and granular activated carbon. J. Sanit. Environ. Eng. 17 (3), 269-276.

Eisler, R., 1989. Atrazine hazards to fish, wildlife and vertebrates: a synotic review. U.S. Fish and Wildlife Service Biology Reports. 85, 1-18.

Elshafie, A., AlKindi, A.Y., Al-Busaidi, S., Bakheit, C., Albahry, S.N., 2007. Biodegradation of crude oil and n-alkanes by fungi isolated from Oman. Mar. Poll. Bull. 54 (11), 1692-1696.

Fan, X., Song, F., 2014. Bioremediation of atrazine: recent advances and promises. J. Soils Sediment. 14, 1727-1737.

Fiskesjo, G., 1985. The Allium test as a standard in environmental monitoring. Hereditas 102, 99-112.

Fontana, R.C., Silveira, M.M., 2012. Influence of pectin, glucose, and pH on the production of endo- and exo-polygalacturonase by Aspergillus oryzae in liquid medium. Braz. J. Chem. Eng. 29 (4), 683-690.

Getenga, Z., Dörfler, U., Iwobi, A., Schmid, M., Schoroll, R., 2009. Atrazine and terbuthylazine mineralization by an Arthrobacter sp. isolated from a sugarcanecultivated soil in Kenya. Chemosphere 77 (4), 534-539.

Ghosh, P.K., Philip, L., 2006. Environmental significance of atrazine in aqueous systems and its removal by biological process: an overview. Glob. NEST J. 8 (2), 159-178.

Kabra, A.N., Ji, M.-K., Choi, J., Kim, J.R., Govindwar, S.P., Jeon, B.-H., 2014. Toxicity of atrazine and its bioaccumulation and biodegradation in a green microalga, Chlamydomonas mexicana. Environ. Sci. Pollut. Res. 21 (21), 12270-12278.

Kaufman, D.D., Blake, J., 1970. Degradation of atrazine by soil fungi. Soil Biol. Biochem. 2, 73-80.

Kolekar, P.D., Phugare, S.S., Jadhav, J.P., 2014. Biodegradation of atrazine by Rhodococcus sp. BCH2 to N-isopropylammelide with subsequent assessment of toxicity of biodegraded metabolites. Environ. Sci. Pollut. Res. 21 (3), 2334-2345.

Lopes, M.S.S., Oliveira, P.C.C., Andrade, M.V.F., Araújo, R.S., Marinho, G., Rodrigues, K., 2011. Removal of macronutrients from effluent of a cashew nut industry by using a batch aerobic reactor with fungal inoculums. J. Sanit. Environ. Eng. 16 (1), 17-26.

Mudhoo, A., Garg, V.K., 2011. Sorption, transport and transformation of atrazine in soils, minerals and composts: a review. Pedosphere 21 (1), 11-25.

Nwani, C.D., Lakra, W.S., Nagpure, N.S., Kumar, R., Kushwaha, B., Srivastava, S.K., 2010. Toxicity of the herbicide atrazine: effects on lipid peroxidation and activities of antioxidant enzymes in the freshwater fish Channa punctatus (Bloch). Int. J. Environ. Res. Public Health 7 (8), 3298-3312.

Papagianni, M., 2007. Advances in citric acid fermentation by Aspergillus niger: biochemical aspects, membrane transport and modeling. Biotechnol. Adv. 25, 244-263.

Pereira, L., 2013. Persistent organic chemicals of emerging environmental. In: Malik, A. Grohmann, E., Akhtar, R. (Eds.), Environmental Deterioration and Human Health: Natural and Anthropogenic Determinants. Springer, Netherlands, 163-213.

Raimbault, M., 1998. General and microbial aspects of solid substrate fermentation. Elect. J. Biotechnol. 1 (3), 174-188.

Ramadevi, C., Nath, M.M., Prasad, M.G., 2012. Mycodegradation of malathion by soil 
fungal isolate Aspergillus niger. Int. J. Basic Appl. Chem. Sci. 2, 2073-2277.

Sánchez-Sánchez, R., Ahuatzi-Chacón, D., Galíndez-Mayer, J., Ruiz-Ordaz, N., SalmerónAlcocer, A., 2013. Removal of triazine herbicides from aqueous systems by a biofilm reactor continuously or intermittently operated. J. Environ. Manag. 128, 421-426.

Satyavani, G., Chandrasehar, G., Varma, K.K., Goparaju, A., Ayyappan, S., Reddy, P.N., Murthy, P.B., 2012. Toxicity assessment of expired pesticides toGreen algae Pseudokirchneriella subcapitata. ISRN Toxicol., 1-10.

Sene, L., Converti, A., Secchi, G.A.R., Simão, R.C.G., 2010. New aspects on atrazine biodegradation. Braz. Arch. Biol. Technol. Int. J. 53 (2), 487-496.

Silva, M.C.F., Antunes, A.A., Lins, C.I.M., Parente, A.H., Pereira, S.V., Takaki, G.M.C., 2013. Remoção do fenantreno por biomassa viva e inativada de Cunninghamella elegans ucp0542 (removal of phenanthrene by living biomass and inactivated of Cunninghamella elegans ucp0542). E-xacta Res. 6 (1), 1-8.

SINDAG, 2011. Sindicato Nacional da indústria de produtos para defesa agrícola, Uso de defensivos é intensificado no Brasil panorama (Pesticide use is intensified in Brazil overview, 2011). 〈http://www.sindag.com.br/noticia.php?News_ID $=2278$ (acessed 28.03.13).
Solomon, E.I., Sundaram, U.M., Machonkin, T.E., 1996. Multicopper oxidases and oxygenases. Chem. Ver. 96, 2563-2605.

Solomon, K.R., Carr, J.A., Du Preez, L.H., Giesy, J.P., Kendall, R.J., Smith, E.E., Van Der Kraak, G.J., 2008. Effects of atrazine on fish, amphibians, and aquatic reptiles: a critical review. Crit. Rev. Toxicol. 38 (9), 721-772.

Tortora, G.J., Funke, B.R., Case, C.L., 2012. Microbiologia (Microbiology). Publishers Artmed, Porto Alegre.

Vonber, D., Vanderborght, J., Cremer, N., Putz, T., Herbst, M., Vereecken, H., 2014. 20 years of long-term atrazine monitoring in a shallow aquifer in western Germany. Water Res. 50, 294-306.

Wang, X., Gong, Z., Li, P., Zhang, L., Hu, X., 2008. Degradation of pyrene and benzo(a) pyrene in contaminated soil by immobilized fungi. Environ. Eng. Sci. 25 (5), $677-684$.

Xie, S., Wan, R., Wang, Z., Wan, Q., 2013. Atrazine biodegradation by Arthrobacter strain DAT1: effect of glucose supplementation and change of the soil microbial community. Environ. Sci. Pollut. Res. 20, 4078-4084. 